\title{
Immigrant Labor and the Issue of "Dirty Work" in Advanced Industrial Societies
}

\author{
Vernon M. Briggs, Jr. \\ Cornell University
}

n

Of the multiple explanations for the post-World War II immigration experiences of those advanced industrial nations where the phenomena occurred, the most pernicious has been that immigrants are needed to do Whe "dirty work." Despite the fact that efforts to characterize the general employment patterns of immigrants in different industrial societies "has proved frustrating," Michael Piore observed in 1979 that "the only immi1. vrant jobs that seem common throughout the industrial world are menial [ jabs" (Piore, p. 19). Likewise, much of the debate in the United States that preceded the enactment of the Immigration Reform and Control Act of 1986 (IRCA) centered on the efficacy of the assertion that the United States economy actually needed illegal immigrants to fill certain menial jobs that would not otherwise be filled (Bustamonte, 1978; Cornelius, 1978).

The general thesis of efforts made to explain these tendencies has been that the structure of labor markets changes over time. As advanced industrial societies have evolved over the past two centuries from being agriculturally based societies, their occupational opportunities have become considerably more diverse. Nonetheless, some labor economists have argued that, by the late twentieth century, many of these societies have sustained perceptable patterns of job clustering. They have witnessed the creation of a dual labor market (Piore \& Doeringer, 1971). Under this ạnalysis, these economies generate both primary sector jobs (i.e., jobs 
characterized as having high wages, good fringe benefits, job security, and promotion opportunities) and secondary sector jobs (i.e., jobs characterized as having low wages, few fringe benefits, little security, and are of a dead-end nature). The relevant question, therefore, has been how do these advanced societies find workers to fill these secondary sector jobs?

The answer in earlier periods was that employers looked for potential workers from the domestic labor force who were at the margins of the labor force-youths, housewives, farmer-workers, and minorities. For a variety of reasons, it has become increasingly difficult in recent decades to recruit from these traditional sources. Youth in advanced industrial societies do not identify with the work behavior of adult workers. When youth do work, it is often because they have an earnings target (i.e., a car, a stereo, a "Spring break"), not because they must support themselves or others. Married women in advanced industrial societies are increasingly thinking in terms of careers and are bearing fewer children that require their physical presence at home. Farmer-workers are rapidly declining in advanced industrial societies because the number of farmers is rapidly diminishing. Hence, there are fewer farmers available for off-season or for dual job holding employment opportunities in the nonagricultural sectors. As for racial and ethnic minorities in these advanced industrial societies, they have been empowered in recent decades with the ideal of equal employment opportunity and reinforced by related public policies that have been designed to enhance their preparation for inclusion into the employment mainstream of these societies. Hence, they too have become less available.

It has been argued, therefore, that the ideal source of labor to fill such menial jobs in these advanced economies are temporary immigrant workers from other (usually less economically developed) countries. In western Europe, they, were known as "guestworkers" during the 1950s, 1960 s and early 1970s. In the United States, they have been "braceros" (from 1942 to 1964) who were seasonal agricultural workers from Mexico; various classifications of nonimmigrant workers admitted for temporary periods of time (e.g., formerly called $\mathrm{H}-2$ workers from 1952 to 1986 but now known as $\mathrm{H}-2 \mathrm{~A}$ or $\mathrm{H}-2 \mathrm{~B}$ temporary workers in agriculture and nonagriculture respectively) to fill unskilled jobs; and, a substantial portion of the illegal immigration flow who, it was alleged, only come to work for short periods of time before returning to their homelands.

The issue of filling menial jobs with immigrants (regardless of whether they are technically classified as legal immigrants, illegal immigrants, or some form of temporary nonimmigrants) goes deeper than the mere issue 
of the availability of alternative sources of labor, It is also associated with the notion that certain jobs in these advanced societies have become socially stigmatized as being unattractive to native born workers who, it is alleged, will not apply for such jobs-presumably at any wage rate. It was contended that these foreign workers did not care about the menial status of the jobs since they saw themselves and their future as being outside of these advanced industrial countries back in their homelands. Piore has described this phenomenon as follows:

From the perspective of the migrant, the work is essentially asocial: it is purely a means to an end. In this sense, the migrant is initially a true economic man, probably the closest thing in real life to the homo economicus of economic theory. (Piore, 1979, p. 54).

But the universal experience with all of these endeavors has been that no immigrant stream of unskilled foreign workers to industrialized societies remains temporary for long. Rather, the process becomes institutionalized both in the sending and the receiving countries. In all of the above cited instances, the lesson that was proven was that it was far easier to start such endeavors than to stop them (Bohning, 1984; Galarza, 1964; Miller \& Martin, 1982). As Piore has explained, "the migration streams that start out as temporary seem to develop over time into settlements of more or less permanent residents; these residents, in turn, have children who are natives - native in terms of their attitudes and motivations, and often quite hiterally natives as well" (Piore, 1979, p. 60). Thus, as the transient intentions of such immigrant workers give way to settlement outcomes, the attitudes of the first generation immigrants as well as their offspring gradually change toward accepting the social attitudes of the new society to which they become a part. As a consequence, these new attitudes inevitably bring them into competition for jobs with the native population" [Piore, $1979, p .81]$. Thus, even if there originally may have been a segmented labor market in which new unskilled immigrants fill a real employment vacuum, the settlement process will eventually bring them into contact with the bottom wrungs of the nation's job hierarchy. For in every industhat society there will always be a bottom of the job hierarchy, by definiion. Hence, if direct job competition between unskilled immigrants and atskilled members of the citizen labor force is not an original intention, it soin becomes the actual reality. 


\section{CHANGING LABOR DEMAND CONDITIONS}

In western Europe, the economic conditions suddenly changed following the first Arab oil boycott in 1973 and 1974. Prices skyrocketed and so did unemployment. Western Europe, which had generally experienced low unemployment (relative to the United States) throughout the preceding two decades, suddenly sustained quantum increases. These rates quickly exceeded those in the United States. Indeed, Europe's unemployment rates have generally remained high ever since (Standing, 1986). The issue of labor surpluses emerged to replace concerns about labor shortages. As a consequence, the official use of foreign workers in these countries came to a rapid end although the phenomena has continued as illegal immigration and by policy allowances for subsequent family reunification to take place (Castles, 1984).

In the United States, civilian unemployment rates, while lower than Europe, have remained high (never falling below an annual rate of $5.3 \%$ since the early 1970 s and averaging over $6.7 \%$ over the entire period). The national unemployment rate, however, has concealed the fact of the much worse experiences of segments of the work force-especially among minorities and youth in general and those workers in central cities of metropolitan areas in particular. The pace and scope of technological change, enhanced international competition, changing consumer spending patterns, and fluctuating national defense expenditures have exerted wrenching structural changes on the U.S. labor market (Marshall \& Briggs, 1.989, chapter 4). The jobs most adversely impacted by these changes have been those in the unskilled job occupations (Cyert \& Mowery, 1987, chapters 1, 3 and 4). Without being diverted into a lengthy explanation as to why this is the case, the unchallengeable consequence can be seen in Table 1.

Table 1 shows the actual occupational growth patterns of the U.S. economy from 1978 to 1990 , a timespan when the overall number of employed persons increased by an incredible 22.1 percent. Over this period of twelve years, professional, and technical occupations accounted for a phenomenal 52 percent of the total number of jobs created. These occupations tend to have the highest educational and training requirements of the entire work force. On the other end of the spectrum, the relatively unskilled occupations of private household workers, laborers, and farm workers all sustained negative growth rates and declining shares of the nation's work force. So did the semiskilled occupation of machine operator. Although there was an academic debate during the 1980 s over whether the types of jobs that were being created required more or less in the way of human capital endowments, the decade is over. The evidence 


\section{Actual Percentage Growth and Percentage Share for Major Occupational Groups in U.S. Economy Between 1978 and 1990 (percentage terms)}

\begin{tabular}{ccc} 
Major Occupation & $\begin{array}{c}\text { Percentage } \\
\text { Increase (or decrease) } \\
\text { from } 1978 \text { to } 1990\end{array}$ & $\begin{array}{c}\text { Share of Employment } \\
\text { Increase (or decrease) }\end{array}$ \\
\hline
\end{tabular}

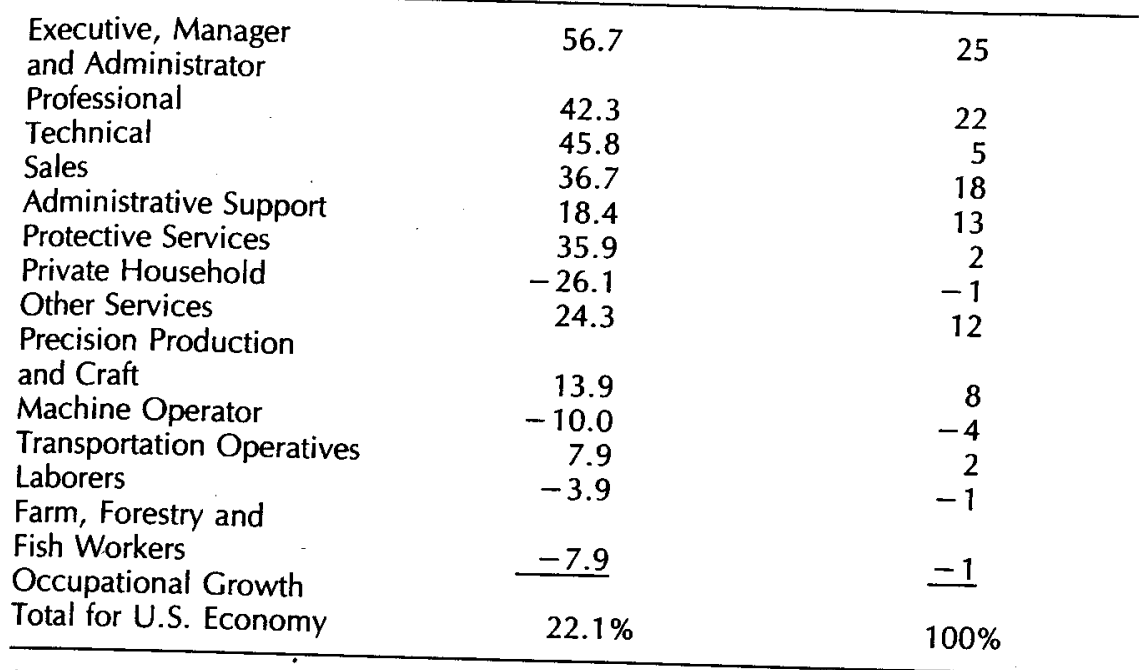
Source: John H. Bishop and Shani Carter, "How Accurate are Recent BLS Occupational Pro-
jections?" Monthly Labor Review, (October 1991) p. 38.

clearly shows that the jobs that are increasing are those with the highest education and skill requirements while those jobs that are declining are overwhelmingly the ones that require the least in the ways of human capital preparation [Bishop \& Carter, 1991, pp. 37-43].

A confirmation of these trends has also been found with regard to the movement of real wages. Workers in the occupations that require extensive education and skill preparation received higher wages over the decade of the 1980s while those that did not require such prerequisites sustained declining real wages (Bishop \& Carter, 1990, pp. 2-3). The real wage trends, therefore, indicate the existence of labor shortages among the ranks of the higher skilled work force coexisting with significant labor surpluses among the less skilled labor force. 
In its projections of occupational growth to the year 2000, the U.S. Department of Labor forecasts that the managerial, professional, and technicians occupations-all of which require postsecondary levels of education and training-are expected to continue to grow much faster than the projected average growth rate for total employment (Silvestri \& Lukasiewicz, 1987, pp. 46-63). Of the 20 occupations projected to be the fastest growing in the 1990s, half are related to the computer and health fields. The shift to a service-based economy is leading to a general upgrading of the skill and educational requirements of the labor force from what had ever previously existed. Conversely, of course, those occupations that require minimal skills and education have sharply contracted and are projected to continue to do so. To make matters worse, these "official" projections have in the past seriously underestimated the severity of these occupational shifts and it is very likely that this will also be the case of the year 2000 projections (Bishop \& Carter, 1991).

Thus, the first reason why unskilled immigrants should not be recruited for low wage menial jobs is that the parameters have changed in the 1980s and 1990s from those of the 1960s and 1970s. Unskilled jobs are contracting in industrial societies. If immigrants are unqualified for the types of jobs that are expanding, the only alternative is that they will be forced to compete in a more intensive manner with those native born unskilled job seekers in these industrial societies for the diminishing number of unskilled jobs that remain. It may also mean that the immigrants will become unemployed, or be forced either into the underclass of these societies or into lives of dependency. It is unlikely, given the extensive welfare systems of these industrial societies, that unsuccessful low skilled immigrants will return to their third world homelands.

\section{CHANGING LABOR SUPPLY CONDITIONS}

The rapid changes in the conditions of the demand for labor have exposed in the United States the stark reality that the nation already has a chronic surplus of workers who are poorly prepared for the new work requirements. In 1987, an independently conducted study funded by the U.S. Department of Labor and entitled, Workforce 2000, warned that the United States was facing the prospect of a serious crises in the work place (Hudson Institute, 1987). It warned that a mismatch was developing between the requirements of jobs that were expanding and the qualifications of the future work force to meet them. In 1989, a follow-up study found that, in fact, "the crisis envisioned in Workforce 2000 has already begun to emerge" (Commission on Workforce Quality, 1989). Its final report stated: 
Increased demand for highly skilled workers, combined with an aging labor force, has already created shortages of skilled workers, shortages that are likely to grow for many years. At the same time, many low skilled workers are having increasing difficulty finding employment (p. 1).

The "skills gap" that was identified by the Commission has developed as a consequence of the lack of preparedness of new labor force entrants as well as the tendency toward rapid obsolescence of the skills of much of the experienced work force. The retraining of the experienced labor force, however, has been hindered by the fact that the basic reading and computational skills that an effective program requires have prerequisites that "are well beyond those currently possessed by many experienced workers" ( $p$. 3). It further, noted that "at least 20 million, and possibly as many as $\mathbf{4 0}$ million, adults today experience substantial literacy problems" (p. 3; see also Kozol, 1985). In accepting the report, Elizabeth Dole, then the U.S. Secretary of Labor, described the U.S. labor force being "woefully inadequate" for the demands expected of it (New York Times, 1989, p. A-9).

No advanced industrial nation at this juncture of time that has as many functionally and marginally illiterate workers as does the United States need have any fears of any shortage of unskilled workers in its immediate future. Indeed, the major dilemma facing the United States is that it already has far too many unskilled workers at a time when the demand for such workers is rapidly contracting. Moreover, with a national high school drop out rate of $25 \%$ and with the dropout rate for blacks approaching $40 \%$ and for Hispanics being over $50 \%$ (the two most rapidly growing components of the youth cohort), it is clear that the pool of unskilled workers available to do menial work is in the process of being significantly enlarged (Joint Economic Committee, 1988, p. 1). As if the high dropout rate was not bad enough, the poor quality of education that is being provided for many students only adds more certainty that the nation's unskilled labor pool and/or the underclass will have plenty of future members. As a recent congressional report stated that many "students graduating from high school now lack the basic reading, writing, and mathematics competency as well as 'higher order' thinking and learning skills demanded by the competitive, computerized economy, and the jobspecific training to move into slots in business and industry" (Joint Economic Committee, 1988, p. 14).

Thus, the second reason why the United States should not-and other advanced industrial nations no longer do--admit unskilled immigrants into their labor forces is that there already exists a surplus supply of potential citizen and resident alien workers for these types of jobs. If immigrants are 
also sought for such jobs, the potential pressure to tap this domestic pool of workers is diminished.

\section{CHANGING LOW WAGE LABOR MARKET DYNAMICS}

Traditionally, low wage jobs reflect the existence of a surplus of applicants relative to existing labor demand opportunities. It is also usually the case that the jobs require little in the way of human capital preparation. The low wages reflect the fact that virtually anyone can perform the required tasks. Hence, unskilled workers not only compete with other unskilled workers for the available jobs but they also are in potential competition with all other workers: Semiskilled and skilled workers who can do unskilled work if times get tough and they cannot find jobs for which they are qualified or if they want to "moonlight" in a second job on a part-time basis. It is always possible for over-qualified workers to work in jobs below their abilities but the reverse is seldom possible except at a high cost of inefficiency.

Thus, it is the economic conditions in the way of alternative earnings opportunities that sets the terms of availability of workers for menial jobs. It is not social attitudes. U.S. workers have shown an unrelenting willingness to work in blue collar occupations in the construction, mining, and manufacturing industries even though the work is dirty, repetitious, and often dangerous, if the renumeration is higher than what they can earn elsewhere. Likewise, there has never been any difficulty finding workers who wish to collect garbage in New York City or San Francisco where such jobs are unionized, well paid, offer significant fringe benefits, and provide uniforms. In other communities where these conditions do not exist, it has proven difficult to find such sanitation workers. Likewise, the agriculture industry has long been noted for its quest to keep wages low for workers while at the same time complaining that it is difficult to find workers who want to do the work. But this is not a failure due to any imagined social resistance to do such work as it is the normal consequence of efforts to keep agricultural wages low and working conditions poor. It is of interest to note that during the period when western Europe was recruiting immigrant workers, they were not employed in agriculture. Despite the fact that the work was as dirty, as demanding, and as dangerous as it is in the United States, the agricultural sector in western Europe did not experience any labor shortages. The reason, of course, is that the industry is significantly subsidized by these governments, which has made the industry economically competitive for workers with their nonagricultural-sectors (Cohen, 1992, p. E-3). 
As noted earlier, Piore has argued that it has at times been difficult in industrial societies to recruit job holders from these pools-especially for certain occupations that are stigmatized as being "dirty." The time frame that Piore and the other previously-cited authors studied was the 1960s and 1970s. It preceded the era when unskilled jobs began to contract, when unemployment began to soar, and when the pool of displaced unskilled workers and poorly prepared new labor market entrants began to expand in the 1980s and early 1990s. In this new economic environment, it is far from clear that the circumstances described by the aforementioned writers of that earlier era continue to exist. Anecdotal evidence suggests otherwise. For instance, when a Sheraton hotel took applications for 500 entry level jobs as busboys, waiters, maids, and custodians for a new hotel in Chicago to open in early March 1992, over 9,000 persons showed up to be interviewed (New York Times, 1992, p. A-1 and A-24).

Likewise, in western Europe in the 1990s all discussion of general labor shortages has vanished from the political scene. The persistence of high unemployment rates have caused the issue of labor surpluses to come to the forefront. Restrictive immigration policies have become the rule in all of the countries of the European Economic Community-especially restrictions on unskilled labor (Whitney, 19891, p. A-1 and A-8; Miller, 1991). It may well be that the western European experience with guestworkers in the 1950-1973 era was an aberration. Its explanation may rest with understanding the unique historical circumstances that produced the extraordinarily tight labor markets of the post-World War II generation (i.e., nations whose physical economies and prime working-aged labor force had both been devastated) rather than from seeking meaning from the
sociology of occupations.

In a free labor market, there is nothing that says that certain types of jobs that are crucial to the performance of certain industries in an economy must be poorly paid. The normal operation of supply and demand forces should see to it that important and useful work is renumerated at levels that will compete with job alternatives. Or, if suich work becomes too costly for employers, that they either improve efficiency by improving management skills or by substituting cheaper capital intensive technologies for labor. But this paradigm is usually described in terms of a closed economy in
which the size of the labor pool is fixed in the short run.

Once immigrants are added as an on-going supply of workers to a particular segment of a nation's labor market, however, the entire $d y$ namics change. The supply of labor increases and, in the case of the United States where the phenomenon of mass immigration is once more a stark reality and where a disproportionate number of unskilled immigrants are entering from less economically developed nations, it may even appear 
to employers that the supply of such unskilled labor is infinite at almost any legal wage rate. In these circumstances, the addition of unskilled workers from third world backgrounds who are often poorly educated, poorly trained, and frequently speak little English into low wage labor markets can have devastating effects on the employment opportunities for native-born and resident-alien job seekers. For such immigrants will do whatever it takes to survive. They will work multiple jobs, double or triple up families in housing, work in violation of child labor laws and other employment standards (Bouvier \& Briggs, 1988, chapter 6; Martin, 1988, pp. 67-91; Marshall, 1988, pp. 181-198). Literally speaking, no citizen or permanent resident alien can compete with such workers. Moreover, the presence of such immigrant labor exerts a narcotic effect on employers in low wage industries. They become addicted to their presence and become convinced that citizens and permanent resident aliens will no longer do this type of work. But it is the presence of substantial numbers of unskilled immigrant workers in these low wage labor markets that makes these conclusions of employers little more than self-fulfilling prophesies.

Furthermore, as immigrants move into these low wage labor markets, ethnic networking frequently takes over and open market competition for jobs ceases (Bogen, 1987, chapter 7; Martin, 1988, pp. 67-91). Thus, market forces, that would otherwise serve to raise wages and make jobs more attractive, are tempered; and institutional hiring processes foreclose the recruitment of the native born and of resident aliens. Incentives to improve management skills or to introduce labor saving technologies are forestalled.

Without the additional presence of unskilled immigrant workers, the existence of menial jobs means that native-born workers and resident aliens must be attracted to them. Menial jobs, however, are not an entirely bad thing for a labor market to offer. Indeed, within legal bounds, these jobs have a useful role to play. For instance, they provide entry opportunities to workers who lack sufficient education and training to qualify for better jobs. They provide valuable work experience to such persons in the form of on-the-job learning - which is itself a form of human capital acquisition. Simply by having access to a job, the job holder is often placed into a job information network within the enterprise and among coworkers with family and friend connections in other enterprises as well.

Even in those circumstances where the specific jobs are dead-end with respect to promotion opportunities, these jobs can still have other social valve. In the case of low income families, for instance, they afford opportunities for multiple members of the family to earn incomes that, when collectively summed, can provide a liveable margin above what can be 
provided by either welfare income alone or earned by a single low wage earner.

Thus, the third reason not to admit unskilled immigrants is that their presence adversely alters the labor market dynamics for citizen job seekers. Low wage jobs are a stepping stone for many individuals and families to a better quality of life. Without these jobs, key segments of the nation's labor force-youth, women, and minorities-have the much more difficult task of entering the labor market without the benefit of access to these entry occupations to reach higher wrungs on the economic ladder.

\section{CONCLUDING OBSERVATION}

The use of immigrants for doing the "dirty work" is often little more than an employer subsidy by the government. Immigration, after all, is a discretionary act of the federal government. Their presence may lower the immediate private costs to employers, but it often raises the longterm social costs to society. These costs are not only the denial of job and earning opportunities for citizen and resident alien workers. They are often manifested in the form of additional governmental benefits provided to the immigrants themselves (i.e., food stamps, rent subsidies and welfare to families as well as the cost of education, school meal programs, health care, and work-study programs for their children). For few immigrant families can survive indefinitely in the United States earning low wages even if the nation allows them to live under third world standards. It also makes it very difficult, if not impossible, for such workers to be organized into effective trade unions.

Thus, to the degree that immigration is viewed as a method of providing low wage workers to do the "dirty work" in industrial societies, it is analogous to a suggestion to take a short cut through quicksand. The end result is a disaster for all who are involved.

\section{REFERENCES}

Bishop, J. \& Carter, S. (1990). The deskilling versus upskilling debate: The role of BLS statistics. Ithaca: Center for Advanced Human Resource Studies, Cornell University, Working Paper \# 90-14.

Bishop J. \& Carter, S. (1991). How accurate are recent BLS occupational projections? Monthly Labor Review, (October).

Bogen, E. (1987). Immigration in New York, New York: Praeger Publishing Co.

Bohning, W.R. (1984). Studies in international labour migration. London: Macmillan Press. 
Bouvier, L. \& Briggs, V. (1988). The population and labor force of New York, Washington, D.C: The Population Reference Bureau.

Bustamonte, J. (1978). Commodity migrants: Structural analysis of Mexican immigration to the United States. In Stanley R. Ross (ed.). Views across the border, pp. 183-203. Albuquerque: University of New Mexico Press.

Castles, S. (1984). Here for good: Western Europe's new ethnic minorities. London: Pluto Press Ltd.

Cohen, R. (April 12, 1992). Life can be sweet on Europe's subsidized Farms. N.Y. Times.

Commission on Workforce Quality and Labor Market Efficiency (1989). Washington, D.C.: U.S. Department of Labor.

Cornelius, W. (1978). Mexican migration to the United States: Causes, consequences and U.S. responses. Cambridge: Center for International Studies of the Massachusetts Institute of Technology.

Cyert, R. \& Mowery, D. (1987). Technology and employment. Washington, D.C: National Academy Press.

Doeringer, P. \& Piore, M.J. (1971). Internal labor markets and manpower analysis. Lexington: D.C. Health.

Galarza, E. (1964). Merchants of labor: The Mexican bracero program. Charlotte: McNalley and Loftin Publishers.

Hudson Institute (1987). Workforce 2000: Work and Workers for the Twenty-First Century, Washington, D.C: U.S. Department of Labor.

Joint Economic Committee of the Congress of the United States (1988). The education deficit. Washington, D.C: U.S. Government Printing Office.

Marshall, R. and Briggs, V.M. (1989). Labor economics, 6th Edition. Homewood: Richard D. irwin, inc.

Marshall, R. (1988). Immigration in the Golden State: The tarnished dream. In David E. Simcox (Ed.). U.S. Immigration in the 1980s. Boulder: Westview Press.

Martin, P. (1988). Network recruitment and labor displacement. In David E. Simcox U.S. Immigration in the 1980s. Boulder: Westview Press.

Miller, J. (September 15, 1991). Strangers at the gate: Europe's immigration crisis. New York Times, pp. $33 \mathrm{ff}$.

Miller, M. \& Martin, P. (1982). Administering foreign-worker programs. Lexington: D.C. Heath and Company.

New York Times, (September 2, 1989), U.S. Study says work force is suffering from shortages.

New York Times (March 1, 1992), Refugees from recession fill hotel's payroll.

Piore, M.J. (1979): Birds of passage: Migrant labor and industrial societies. London: Cambridge University Press.

Silvestri, G.T. \& Lukasiewicz, J.M. (1987). A look at occupational employment trends to the year 2000. Monthly Labor Review, (September).

Standing, G. (1986). Labor surplus and labor flexibility: A European perspective. In Howard Rosen (Ed.). Job generation: U.S. and European perspectives. Salt Lake: Olympus Publishing Company.

Whitney, C.R. (December 29, 1991), Europeans look to new ways to bar door to immigrants. New York Times. 